\title{
Offending Officials: Former Government Actors and the Political Offense Exception to Extradition
}

\author{
Aimée J. Buckland $\dagger$
}

\section{INTRODUCTION}

Generally, the political offense exception is a defense against extradition. The exception provides that those who commit crimes of a political nature, in the context of a political struggle, should not be extradited as though they had committed ordinary crimes and fled the country to avoid being brought to justice. The original purpose of the political offense cxception to extradition was to protect revolutionaries from being returned to their home countries to face prosecution for crimes committed against their governments. Since the political offense exception's noble beginnings in the 1700s, however, the world has changed greatly. As a result, the policy rationales for allowing the political offense exception have become more complicated. Historically, the exception's functions were to protect revolutionaries and to prevent excessive involvement in the political affairs of countries requesting extradition. Today, the exception encompasses a greater range of actors. Courts grapple with circumstances involving armed conflict, war criminals, asylum seekers, former government officials, and terrorism. In response to criticism that terrorists use the exception as a loophole to avoid extradition, ${ }^{1}$ extradition treaties have evolved to exclude

Copyright $(2006$ California Law Review, Inc. California Law Review, Inc. (CLR) is a California nonprofit corporation. CLR and the authors are solely responsible for the content of their publications.

$\dagger \quad$ J.D. candidate, School of Law, University of California, Berkeley (Boalt Hall), 2006; B.S.W, University of Kansas; M.S.W., Washington University in St. Louis. I would like to thank my fellow editors of the California Law Review, and cspecially Meliah Thomas, for all of their hard work on this Comment. I also express my deepest gratitude to my parents, Herbert and Sara Buckland, and my sisters, Carrie and Leanna, for their unfailing support and encouragement.

1. See generally Valerie Epps, U.S.-UK Extradition Treaties-Rule of Expanded Political Offense-Type Exception, 90 Am. J. INT'L L. 296 (I996); Daniel T. Kiely, Jr., Notc, The Compromise Between Outrage and Compassion: Article 3(a) and In re Requested Extradition of Smyth, 30 Cornell Int'L L.J. 587 (1997); Antje C. Petersen, Note, Extradition and the Political Offense Exception in the Suppression of Terrorism, 67 IND. L.J. 767 (1992); David M. Rogers, Case Comment, In re Extradition of Singh, $170 \mathrm{~F}$. Supp. $2 d 982$ (E.D. Cal. 200l), 26 Suffolk Transnat'l L. Rev. 
terrorist activity from categories of crimes considered to be political offenses. ${ }^{2}$

Thus far, however, the law is unsettled as to whether former government officials may use the political offense exception and whether the exception is appropriate in this context. The literature rarely addresses these issues, largely because of the disconnection between the exception's historical purpose and its current application. ${ }^{3}$ Arguably, everything a government actor does is "political." Therefore, the exception theoretically protects former government officials from facing their accusers merely because they used to govern them. ${ }^{5}$

This Comment examines the difficulties of applying the political offense exception to former government officials by analyzing the case of Gonzalo Sánchez de Lozada, former president of the Republic of Bolivia. During his short presidency, which was marked by massive nationwide protests, Sánchez de Lozada allegedly was responsible for the deaths of approximately eighty civilians and the injuries of hundreds more. ${ }^{6} \mathrm{~A}$ concrete analysis of Sánchez de Lozada's case emphasizes the predicaments that arise when the political offense exception is asserted by former government officials. Although the current Bolivian government has taken steps toward requesting Sánchez de Lozada's extradition from the United States, ${ }^{7}$ the outcome of the request is difficult to predict. Before it proceeds, the Bolivian government must ask itself three critical questions: (1) whether it can meet the extradition requirements under the applicable treaty, (2) whether Sánchez de Lozada can successfully invoke the political offense exception as a defense to extradition, and (3) whether the United States will find an avenue to protect its political ally.

Part 1 of this Comment sets the stage for the analysis by describing the context and circumstances leading up to Sánchez de Lozada's forced resignation. Part II gives an overview of the extradition process and analyzes whether Sánchez de Lozada's offenses fall within the U.S.-Bolivia

479 (2003); Miriam E. Sapiro, Note, Extradition in an Era of Terrorism: The Need to Abolish the Political Offense Exception, 61 N.Y.U. L. Rev. 654 (1986).

2. Extradition Treaty, U.S.-Bolivia, art. V, June 27, 1995, S. Treatr Doc. No. I04-22, 1995 U.S.T. LEX1S 221, available at http:/www.oas.org/juridico/MLA/en/traites/en_traites-ext-usa-bol.pdf [hereinafter Extradition Treaty]; see also Quinn v. Robinson, 783 F.2d 776, 782 (9th Cir. 1986) (concluding that the Anglo-American incidence test used to apply the political offense exception also excludes terrorist activity).

3. Christine Van den Wijngaert, The Political Offence Exception to Extradition: The Delicate Problem of Balancing the Rights of the Individual and the International Public Order 3, 18 (1980).

4. Quinn, 783 F.2d at 782 (9th Cir. 1986); In re Requested Extradition of Suarez-Mason, 694 F. Supp. 676, 705 (N.D. Cal. 1988)

5. Quinn, 783 F.2d at 800 n.24.

6. Bolivia's Former President Charged With Genocide, Agence France-Presse, Feb. 22, 2005, http://www.theallineed.com/news/0502/223251.htm.

7. Id. 
extradition treaty. This Part also addresses the issues Bolivia may face in meeting the requirements for extradition. Part III describes the purpose and current case law surrounding the political offense exception. Part IV analyzes whether Sánchez de Lozada ean satisfy the criteria for asserting the exception as a defense to extradition. This Part also explores whether Sánchez de Lozada, as a former government official, should be able to use the political offense exception. The Conclusion asserts that the political offense exception should not apply to former government officials because they have no historic claim to the exception and because they have recourse to other, sufficiently fair defenses.

\section{I \\ Gonzalo Sánchez de Lozada: An Example From Bolivia}

\section{A. Socio-Economic Conditions in Bolivia}

One of the least developed countries in South America, Bolivia struggles to provide for its people and compete economically in the international market. Indigenous people are the numerical majority in Bolivia, estimated to constitute at least $60 \%$ of the population. ${ }^{8}$ However, in terms of wealth distribution, education, and participation in the open-market economy, indigenous Bolivians continue to be the most disadvantaged. ${ }^{9}$ More than twothirds of Bolivians live in poverty, ${ }^{10}$ with rural poverty being the most severe: $90 \%$ of rural Bolivians live in poverty, and $60 \%$ live in extreme poverty. ${ }^{11}$ Approximately $85 \%$ of Bolivians consume fewer than the recommended daily allowance of calories, ${ }^{12}$ and $24 \%$ of children three years of age or younger suffer from chronic malnourishment. ${ }^{13}$ In addition, $60 \%$ of the total population and $78 \%$ of poor rural homes have no access to safe drinking water. $^{14}$ In rural areas, approximately $70 \%$ of homes lack

8. U.S. Department of State, Background Note: Bolivia, Aug. 2004, available at http://www.state.gov/r/pa/ei/bgn/3575l htm. There are about three dozen indigenous groups in Bolivia, including the Quechua (2.5 million), Aymara (2 million), Chiquitano $(180,000)$, and Guarani $(125,000)$. Id.

9. Luz Beatriz Gaviria V., Poverty and Participation Mechanisms of Indigenous Peoples: Lessons from Conflict-Driven Struggles in Bolivia, in BEyond THE SILENCING OF THE Guns 25 (Chandra Roy ed., 2004), available at http://www.undp.org/cso/resource/CSO_perspectives/ beyondSG/chapter2.pdf.

10. United Nations Development Programme, Human Development Report 2003, at 246, available at http://hdr.undp.org/reports/global/2003/pdf/hdr03_HDl.pdf.

11. Fourteen percent of Bolivians attempt to survive on less than one U.S. dollar a day. Amnesty Intemational, Bolivia: Crisis and Justice: Days of Violence in February and October 2003, at 4, http://web.amnesty.org/library/pdf/AMR180062004ENGLISH/SFile/AMR1 800604.pdf [hereinafter Crisis and Justice].

12. Gaviria V., supra note 9, at 26.

13. U.S. Department of State, Country Reports on Human Rights Practices-2003, Released by the Bureau of Democracy, Human Rights, and Labor, Feb. 25, 2004, available at http://www.state.gov/g/drl/rls/hrrpt/2003/27887.htm [hereinafter State Dep't Human Rights Report].

14. Gaviria V., supra note 9 , at 26. 
sanitary services. ${ }^{15}$ Bolivia also has one of the highest maternal and infant mortality rates in the Americas. ${ }^{16}$

As in many developing countries, policies designed to strengthen Bolivia's economy often have had disastrous effects on the poor. ${ }^{17}$ In return for financial aid from the International Monetary Fund (IMF), Bolivia must implement classic conservative fiscal policies. ${ }^{18}$ These policies involve the withdrawal of state subsidies, release of price and currency controls to curb inflation, efforts to decrease the national debt, and trade liberalization. ${ }^{19}$ However, this policy package also includes significant funding decreases for critical social programs that sustain Bolivia's poor and struggling middle class. ${ }^{20}$ Under the "macroeconomic adjustment" agreements with the IMF in 2003, Sánchez de Lozada agreed to reduce Bolivia's fiscal deficit from $8.5 \%$ to $5.5 \%{ }^{21}$ To achieve this deficit reduction, Sánchez de Lozada proposed an income tax ranging from $4.2 \%$ to $12.5 \%$ of annual gross income on Bolivia's low-income workers, including teachers, police, and nurses earning only $\$ 110$ per month. ${ }^{22} \mathrm{He}$ also proposed freezing wage increases that were supported by social and labor organizations. ${ }^{23}$

Sources outside Bolivia have supported and encouraged other controversial policies. For example, Bolivia's access to American markets under the Andean Trade Preferences Agreement is conditioned on adherence to U.S. antidrug policies. ${ }^{24}$ U.S. support for financial aid from international organizations, such as the World Bank and the IMF, also requires Bolivia's compliance with U.S. antidrug objectives. ${ }^{25}$ Bolivia has attempted to meet these objectives largely through the government's coca-eradication program. These efforts have caused great social unrest among many of Bo-

15. Id

16. Fiona Ortiz, Giving Birth Often Means Death for Bolivia's Women, ReUTERs, July 7, 2005 , available at http://www.rednova.com/modules/news/tools.php?tool=print\&id=167586. ("Bolivia has the highest rate of maternal deaths during pregnancy and childbirth and the highest infant mortality ratc of any other country in the Americas except Haiti."). In 2001, the child mortality rate was sixty-seven per one thousand births. Gaviria V., supra note 9, at 26 . The high prevalence of infant mortality is caused by a combination of malaria, tuberculosis, chagas disease, diarrhea, and respiratory infections. Id.

17. Jim Shultz, Deadly Consequences: The International Monetary Fund and Bolivia's "Black February" (2005), at 12-13, http://www.democracyctr.org/publications/imfreport.pdf.

18. Id. at 17-19.

19. Id.

20. Id.

21. Id. at 19 .

22. Id. at 21 .

23. Crisis and Justice, supra note 11, at 5-6. Approximately $66 \%$ of Bolivians live in poverty, the national minimum wage is $\$ 55$ (U.S.) per month, and workers in Bolivia's mining industry earn less than $\$ 2.75$ for a twelve-hour workday. State Dep't Human Rights Report, supra note 13.

24. Andrew Enever, New Government, Same Old Coca War, BBC NEws, Sept. 7, 2002, http://news.bbc.co.uk/2/hi/americas/2242739.stm.

25. Kathryn Ledebur, Special Update: Bolivia, Popular Protest Brings Down the Government, Washington Office on Latin America, Nov. 2003, at 5, http://www.wola.org/publications/ ddhr_bolivia_mcmo_nov2003.pdf. 
livia's poorest citizens, whose livelihoods depend on coca cultivation. ${ }^{26}$ As will be shown in the next Section, organized coca growers played a significant role in the events following Sánchez de Lozada's election to the presidency.

\section{B. The Bolivian Gas War and Sánchez de Lozada's Road to Exile}

Sánchez de Lozada's second term as president did not begin with strong support. ${ }^{27} \mathrm{He}$ took office in August 2002 with only $22.5 \%$ of the country's popular vote, barely beating Evo Morales, leader of the Bolivian federation of coca farmers. ${ }^{28}$ To win the presidency, Sánchez de Lozada formed an "uneasy alliance" with another political party to gain the congressional votes necessary to put him into office. ${ }^{29}$ This alliance plagued the Sánchez de Lozada administration from the start and proved a source of continued infighting. ${ }^{30}$

Within two days of his inauguration, Sánchez de Lozada ordered the military to assist in the eradication of illegal coca crops without scheduling negotiations with coca farmers. ${ }^{31}$ By January 2003, the coca growers erected roadblocks between the major cities of Cochabamba and Santa Cruz in protest of Sánchez de Lozada's coca-eradication policies. When farmers and protesters clashed with governmental security forces in the Chapare region, four people died and hundreds were taken into custody. ${ }^{32}$

As discussed above, Sánchez de Lozada proposed new income taxes in February. ${ }^{33}$ This plan caused a National Police Force revolt and widespread protests in La Paz, Oruro, Sucre, and Santa Cruz. Soldiers tried to subdue the protesters with tear gas and rubber pellets, and snipers were reported around the presidential palace in La Paz. On February 12, Sánchez de Lozada fled the presidential palace by ambulance, subsequently announcing that he would suspend the income tax proposal and other plans

26. Id. at 5. Bolivia is the third-largest coca producer after Colombia and Peru. CIA, The World Factbook: Bolivia, Nov. 1, 2005, available at http:/www.cia.gov/cia/publications/factbook/geos/ bI.html\#Issues.

27. Ledebur, supra note 25, at 2; Goni Gone, But Not Forgotten, THE Economist, Oct. 14, 2004, at 2, available at 2004 WLNR 10897I94. Bolivians have nicknamed Sánchez de Lozada "Goni." Although born in La Paz, Bolivia, in I930, Sánchez de Lozada earned his degree from the University of Chicago, spending significant time in the United States even before his exile. He is often referred to as "gringo" because he speaks with a U.S. accent. During his first presidential term from 1993 to I997, Sánchez de Lozada first implemented the conservative fiscal policies supported by the United States, International Monetary Fund, and the World Bank.

28. Ledebur, supra note 25 , at 2.

29. Id. Because no candidate won a majority of votes, the Bolivian Congress had to vote for the new president.

30. Id.

3I. Enever, supra note 24.

32. Crisis and Justice, supra note I 1 , at 6.

33. Carlos Mesa New Leader in Troubled Bolivia as Former President Quits, Agence FRANCEPresse, Oct. 18, 2003, http://www.commondreams.org/headlines03/I0I8-03.htm [hereinafter Mesa New Leader]. 
for privatization..$^{34}$ The next day, the clashes continued. A young worker repairing a roof near the presidential palace was shot and killed by a military sharpshooter, along with the student nurse who tried to help him. ${ }^{35} \mathrm{~A}$ doctor attempting to help other victims was also wounded. ${ }^{36}$ In two days, thirty-three people died and hundreds were injured. ${ }^{37}$

In mid-September 2003, Sánchez de Lozada began discussing an ambitious plan to build a pipeline to export natural gas through Chile, Bolivia's longtime rival. ${ }^{38}$ Led by labor unions and rural peasants, widespread popular protests erupted against the plan and in general opposition to Sánchez de Lozada's policies. Opponents argued that the $\$ 5$ billion project would benefit only wealthy Bolivians and international oil companies. ${ }^{39}$ In just a few weeks, demonstrators gained momentum and spread the message that "the gas is for the people of Bolivia."40 Gas ownership, they argued, should be returned to Bolivia for the benefit of its impoverished people. ${ }^{41}$ In the small town of Warista, members of the army and police violently confronted local people monitoring the roadblock between La Paz and Sorata. ${ }^{42}$ As a result, five civilians were killed, including an eightyear-old girl. ${ }^{43}$ In addition, the combined security forces allegedly used force to enter the town's secondary school and fired shots at houses. ${ }^{44}$

34. $I d$.

35. Crisis and Justice, supra note 11 , at 7 .

36. Id.

37. Bolivians Want President to Resign, CNN.com, Oct. 17, 2003, http://www.cnn.com/ 2003/WORLD/americas/10/17/bolivia.protests.ap/index.html. On February 13, 2003, amid the chaos, U.S. officials reiterated their support for Sánchez de Lozada:

The United States regrets the loss of life resulting from yesterday's events in Bolivia.

We reiterate our support for President Gonzalo Sánchez de Lozada and the coalition government and urge all Bolivians to respect the constitutionally elected government and refrain from violence.

We welcome the agreement reached between the government and the Bolivian National Police and note the responsibilities of both the police and military in enforcing Bolivia's laws and maintaining order.

The United States believes the parties must continue to work together to resolve their differences. Together with our partners in the international community and the relevant international financial institutions, the United States supports the goals of the government of Bolivia to restore economic stability, continue on Bolivia's democratic path and provide hope for a better life to the Bolivian people.

Press Statement, Richard Boucher, Spokesman, U.S. Dep't of State, United States Expresses Concem With Violence in Bolivia, Feb. 13, 2003, http://www.state.gov/r/pa/prs/ps/2003/17692.htm.

38. The two countries have been rivals since the War of the Pacific from 1879 to 1883 when Bolivia lost its outlet to the sea. Bolivians Want President to Resign, supra note 37.

39. Id.; Mesa New Leader, supra note 33.

40. Crisis and Justice, supra note 11, at 16.

41. Id.

42. Letter from Susan Lee, Amnesty International, to Mr. Yerko Kukoc, the Bolivian Minister of Government, Sept. 23, 2003, available at http://web.amnesty.org/library/Index/ ENGAMR180112003?open\& of=ENG-BOL.

43. Id.

44. Id. 
By the end of what Bolivians call "Black October," and known internationally as "Bolivia's Gas War," additional clashes between civilians and the combined forces had left sixty-nine people dead and several hundred more injured. ${ }^{45}$ Sánchez de Lozada allegedly had authorized the military to use deadly force to suppress the protests. ${ }^{46}$ According to one commentator, "the armed forces and police killed as many people during the fourteenmonth Sánchez de Lozada presidency as during the seven years of General Banzer's dictatorship, considered one of the bloodiest of Bolivia's military governments since the 1952 revolution. ${ }^{.47}$ On the worst days, between October 10 and 12 , soldiers reportedly fired indiscriminately at protesting civilians in El Alto and La Paz. ${ }^{48}$

After October 13, Sánchez de Lozada's vice president, Carlos Mesa, and other high-ranking officials withdrew their support for the president. ${ }^{49}$ The violent suppression of the nationwide protests led to the initiation of a hunger strike by prominent members of the Catholic Church and members of the Permanent Human Rights Assembly. ${ }^{50} \mathrm{~A}$ historic march took place in La Paz on October 16 and ended at the main plaza, where more than 200,000 people gathered and asked the public to join a hunger strike and demand Sánchez de Lozada's resignation. ${ }^{51}$ In addition, U.N. special rapporteurs on torture and the U.N. secretary general on human rights voiced concerns about the "excessive use of force by the army and the police in the course of their ongoing law enforcement operations." 52

At first, Sánchez de Lozada refused to resign, blaming subversive forces from Peru and Colombia for undermining "Bolivian democracy." 53

45. The estimated number of those killed varies from sixty to eighty-six. Ledebur, supra note 25, at 2; Mesa New Leader, supra note 33; Timeline: Bolivia, BBC NEws, Dec. 9, 2004, at $\mathrm{http}: / /$ news.bbc.co.uk/1/hi/world/americas/country_profiles/1218814.stm.

46. Ledebur, supra note 25 , at 2.

47. Id.; Bolivia Backs Trial for Ex-Leader, BBC News World Edition, Oct. 14, 2004, http://news.bbc.co.uk/2/hi/americas/3741980.stm.

48. Crisis and Justice, supra note 11, at 17; see also Jose Antonio Aruquipa, A Blow to Impunity: Congress Gives Green Light to Try Sánchez de Lozada for "Gas War" Killings, Latinamerica Press, Oct. 21, 2004, http://www.lapress.org/article.asp? lssCode $=\&$ lanCode $=1$ \&artCode $=3980$. According to witnesses,

"[T] he military were shooting us down like pigeons." "It is unbelievable, how is it possible that there are humble people, people who have nothing... Yes, they have blocked [the roads with stones...] but they have no weapons, nothing to defend themselves with. And yet the military come and kill them left and right, shooting at houses." "When the soldiers got near us, we thought that they wouldn't do anything to us because we weren't causing any trouble, we thought they would just go peacefully by. The road was not blocked or anything. That was when the soldiers started shooting innocent people. And it wasn't with pistols either, they had machine guns. They had weapons, and there was seven dead [and] seven wounded ...."

Crisis and Justice, supra note 11 , at 20-22.

49. Ledebur, supra note 25 , at 3.

50. Crisis and Justice, supra note 11 , at 17.

51. Id.

52. Id.

53. Ledebur, supra note 25 , at 3. 
Ultimately, however, the Bolivian Congress accepted his resignation on October 17, 2003, in an 84-26 vote during an emergency session. ${ }^{54}$ Later that evening, Carlos Mesa was sworn in as the new Bolivian president as Sánchez de Lozada flew to the United States. Sánchez de Lozada has been living in the United States as a legal visitor ever since. ${ }^{5 s}$

\section{The Case Against Sánchez de Lozada}

On October 13, 2004, nearly one year after his resignation, the Bolivian Congress authorized a Trial of Responsibility against Sánchez de Lozada and his fifteen cabinet members for the Gas War. ${ }^{56}$ Sánchez de Lozada and his cabinet were accused of genocide, which carries a prison sentence of ten to twenty years under the Bolivian criminal code. ${ }^{57}$ Since the vote, the Bolivian Supreme Court has overseen the gathering of evidence to establish Sánchez de Lozada's culpability ${ }^{58}$ Once the investigation is complete, the casc will be tried in the Supreme Court, where a sentence is not subject to appeal. ${ }^{59}$ At the time of the congressional authorization, U.S. Ambassador to Bolivia David Greenlee refrained from speculating on Sánchez de Lozada's possible extradition. ${ }^{60}$ While recognizing the constitutionality of Mesa's presidency, the U.S. State Department issued a statement commending Sánchez de Lozada's commitment to

54. Bolivia's Political Earthquake: Overthrown!, World PREss Rev., Jan. 2004, http:/www.worldpress.org/Americas/1716.cfm; New Bolivia Leader Urges Unity, BBC News, Oct. 18, 2003, http://news.bbc.co.uk/2/hi/americas/3203042.stm.

55. Al Giordano, Wanted: Former Bolivian President is Called to Justice, Narco News Bulletin, Oct. 14, 2004, http://narcosphere.narconews.com/story/2004/10/14/93626/924.

56. "According to the Law of Trials of Responsibilities, the legislature must approve by a minimum of 105 votes to try any president or state official, a process which is carried out by the Supreme Court." Aruquipa, supra notc 48. See also Giordano, supra note 55; Histórico: Goni la Justicia Ordinaria, El MUNDO, Oct. 24, 2004, http://www.elmundo.com.bo/ Secundaria.asp?edicion $=14 / 10 / 2004 \& \mathrm{~T}$ ipo $=$ Nacional\&Cod $=2024 ;$ Goni Gone, But Not Forgotten, supra note 27 , at 2 .

57. Article 138 of the Bolivian Criminal Code defines genocide as follows:

He who, with intent to destroy totally or partially a national, ethnic, or religious group,

kills or causes injury to members of that group, or subjugates them to inhumane subsistence, or imposes measures designed to impede their ability to reproduce, or forcibly displaces children or adults to other groups, will be punished by imprisonment for ten to twenty years.

This or other perpetrators will incur the same punishment, if directly or indirectly culpable for bloody massacres in the country.

If he or other perpetrators are authorities or public officers, the penalty will be increased by 100 to 500 days.

Código Penal [C.P] art. 138 (Bol.) (author's trans.).

58. Lina Britto \& Lucia Suarez, From "Goni Go Home!" to "Goni a Chonchocora!": Bolivia a Year After the October Insurrection, Counterpunch, Oct. 21, 2004, http://www.counterpunch.org/hylton10212004.html.

59. Id. See also Aruquipa, supra note 48 ("It is the second time in history that [the Bolivian] Congress has paved the way for a trial against a former president. Former dictator Luis Garcia Meza, who in 1980 led a bloody military coup, was tried in a process that lasted more than seven years and was sentenced to 30 years in jail with no chance for a pardon.").

60. Giordano, supra note 55. 
democracy and expressing regret regarding the circumstances that led to his resignation. ${ }^{61}$

After October 2004, Bolivian officials continued to move forward with evidence collection, guaranteeing the public that they would requcst Sánchez de Lozada's extradition as soon as possible. ${ }^{62}$ The government also dedicated sufficient economic resources in the country's budget to continue the legal process. ${ }^{63}$ On Fcbruary 21,2005 , the Bolivian attorney general indicted Sánchez de Lozada for genocide "in the form of a bloody massacre" and other crimes. ${ }^{64}$ When asked about these events, a State Department spokesman was unaware of an extradition request and said he would look into the matter. ${ }^{65}$ The State Department later issued a statement confirming that the Bolivian government had not contacted the department concerning the accusations against Sánchez de Lozada. ${ }^{66}$ The statement further noted that "U.S. officials have raised with Bolivian officials our concern that the charges appear to be politically motivated." ${ }^{67}$

In June 2005, the Bolivian Foreign Ministry formally requested that the U.S. State Department serve Sánchez de Lozada with a legal subpoena requesting his return to Bolivia to testify in the Trial of Responsibility ${ }^{68}$ ln response to the State Department's failure to act on this request, U.S. citizens, acting on behalf of Bolivian human rights organizations, served Sánchez de Lozada with legal documents on November 1, 2005. ${ }^{69}$ Since

61. Press Statement, Adam Ereli, Deputy Spokesman, U.S. Dep't of State, Resignation of President Sanchez de Lozada, Oct. 18, 2003, http://www.state.gov/r/pa/prs/ps/2003/25341.htm; Mesa New Leader, supra note 33.

62. Fiscal Priorizará Proceso Contra Sanchez de Lozada, El Diario-Politica, Dec. 17, 2004, http://www.eldiario.net/noticias/nt041217/2_03plt.html (on file with author).

63. Gobierno Garantiza Recursos Para Juicio Contra Sánchez de Lozada, El DiaRIoPoliticA, Jan. 8, 2005, http://www.eldiario.net/noticias/nt050108/2_08plt.html (on file with author)

64. Sánchez de Lozada's former defense ministers Carlos Sanchez Berzain and Yerko Kukoc were included in the charges. Prosecutors also filed lesser charges of complicity against thirteen other former cabinet ministers. Bolivia's Former President Charged With Genocide, supra note 6.

65. U.S. Dep't of State, Daily Press Briefing, Richard Boucher, Spokesman, Feb. 22, 2005, http://www.state.gov/r/pa/prs/dpb/2005/42575.htm.

Question: 1 just wonder if the Government of Bolivia has made contact with you with regard to the accusations to the former President Sanchez de Lozada, who is living in the U.S. Have you had any request of his extradition? MR. BOUCHER: I don't know. I'd have to check. But if it's an extradition request, the Justice Department might be able to decline comment rather than over here. (Laughter.) But l'll check and see if we have anything to say. QUESTION: And are you worried that he is accused of human rights violations and killings Id. and he is living in the U.S.? MR. BOUCHER: l'll have to look into the matter further.

66. U.S. Dep't of State, Office of the Spokesman, State Department Reaction to the Indictment of Former Bolivian President Gonzalo Sanchez de Lozada, Feb. 23, 2005, http://www.state.gov/r/pa/prs/ps/2005/42617.htm [hereinafter Reaction to the Indictment].

67. Id.

68. Press Statement, Juicio a Goni Ya, Exiled Bolivian President Served Legal Documents at Washington Wine and Cheese Reception (Nov. 3, 2005), available at http://juiciogoniya.free.fr/ inicio/article.php3?id_article $=60$.

69. Id. 
then, Evo Morales, Sánchez de Lozada's former political foe, has been voted in as the first indigenous president of Bolivia. ${ }^{70}$ Given Morales' support of Sánchez de Lozada's indictment, the judicial process will likely continue to move forward.

\section{U.S. Protection of a Former Political Ally}

The U.S. government supported Sánchez de Lozada in his presidential campaign and throughout the events leading to his resignation. This support was due to Sánchez de Lozada's conservative economic policies and his enthusiasm for U.S. coca-eradication policies. ${ }^{71}$ Therefore, the success of extradition efforts is closely linked to Sánchez de Lozada's previous and ongoing relationship with the U.S. government.

The United States already has moved to protect Sánchez de Lozada as a former political ally. As mentioned above, the State Department has indicated that it believes the charges against Sánchez de Lozada are politieally motivated. ${ }^{72}$ This assertion is a strong signal that the United States will find some reason, such as the political offense exception, for not extraditing Sánchez de Lozada. Because the Secretary of State ultimately determines Sánchez de Lozada's fate, ${ }^{73}$ the former president is also likely to ask the Secretary to use her discretion and deny extradition. However, unless Bolivia fails to meet the requirements for extradition, it will be difficult for the executive branch to completely circumvent its obligations under the Bolivia-U.S. extradition treaty. The next Part examines whether the Bolivian government will be able to satisfy the requirements for extraditing Sánchez de Lozada from the United States.

\section{II \\ EXTRADITION \\ A. The Mechanics of Extradition}

The right of a foreign nation to demand and obtain extradition of a criminal fugitive is created by treaty. ${ }^{74}$ Under the Supremacy Clause of Article VI of the U.S. Constitution, treaties are on the same hierarchical

70. Hal Weitzman, The Peasants' President, Fin. Times, Jan. 21, 2006, at 11 .

71. Ledebur, supra note 25 , at 6.

72. Reaction to the Indictment, supra note 67.

73. 18 U.S.C. $\S 3186(2000)$.

74. Quinn v. Robinson, 783 F.2d 776, 782 (9th Cir. 1986). A treaty can be self-executing or nonself-executing, depending on whether enabling or implementing legislation is necessary for the treaty to take effect. Extradition treaties tend to be self-executing because their implementation does not require the enactment of legislation. Michael W. Reisman et al., InTERnational LaW in Contemporary PersPective 1310 (2004). The Restatement (Third) of Foreign Relations Law concludes, "In general, agreements that can be readily given effect by executive or judicial bodies, federal or state, without further legislation, are deemed self-executing, unless a contrary intention is manifest. Obligations not to act, or act only subject to limitations, are generally self-executing." RESTATEMENT (THIRD) OF FOREIGN RElations LAW OF THE UNited States $\$ 111$ reporter's note 5 (1987), in Reisman eT al, supra. 
level as acts of Congress. ${ }^{75}$ The extradition treaty between Bolivia and the United States creates a reciprocal obligation to extradite persons within the requested state's territory who have been accused or convicted of certain crimes within the requesting state's territory. ${ }^{76}$ The United States has had an extradition treaty in force with Bolivia since $1900 .^{77}$ The countries renegotiated the treaty in 1995 to "modernize the legal tools" available for the extradition of narcotics traffickers and terrorists. ${ }^{78}$ The treaty includes an official summary of the procedures the United States will follow in response to Bolivian extradition requests. ${ }^{79}$ These procedures dictate the United States' obligations under the treaty in handling extradition requests.

According to the Ninth Circuit, ${ }^{80}$ Bolivia must establish the following six elements to extradite a fugitive from the United States: (1) an extradition treaty in force between Bolivia and the United States; (2) criminal charges pending in Bolivia against the accused; (3) the crimes for which the accused is charged are extraditable crimes within the terms of the treaty; (4) the individual before the Court is the same person charged in Bolivia; (5) the evidence submitted establishes probable cause to believe

75. U.S. Const. art. VI, $\$ 2$.

76. Extradition Treaty, supra note 2, art. I.

77. Treaty of Extradition, U.S.-Bolivia, Apr. 2I, 1900, C.T.I.A. 347.000.

78. "The Treaty represents an important step in combating narcotics trafficking and terrorism, by providing for the mandatory extradition of nationals of the Requested State in a broad range of serious criminal offenses." Letter of Transmittal to the Senate, Oct. 10, 1995, Extradition Treaty, supra note 2. At the time, the United States was changing language in most of its extradition treaties to reflect the various multilateral intemational treaties now in place. Letter of Submittal to the President, Sept. 22, 1995, Extradition Treaty, supra note 2. [hereinafter Letter of Submittal to the President].

79. The letter from the U.S. ambassador to the Bolivian minister of foreign affairs and worship aceompanying the 1995 Extradition Treaty describes the procedures are as follows:

[T]he United States Department of State will accept extradition requests from the Government of Bolivia, and review such requests for compliance with the extradition treaty.

The Department of Justice will review each request and supporting documentation for compliance with U.S. evidentiary and other legal requirements. United States agencies will advise and counsel Bolivia on the strengths and weaknesses of each request, and the need for revisions in the request or for supplementary documentation. The Department of State will prepare a declaration that offense[s] are extraditable.. The Department of Justice will submit the extradition file to the appropriate United States Attomey's Office in the jurisdiction where the person is located, and will arrange for the arrest of the fugitive by filing a complaint for the issuance of an arrest warrant. The United States Attorney's Office will present the request to the appropriate U.S. District Court. United States legal counsel will actively advocate Bolivia's interests in all extradition proceedings in U.S. courts. ...

Extradition Treaty, supra note 2.

80. Although Sánchez de Lozada lives in Florida, which is within the Eleventh Circuit's jurisdiction, this Comment uses Ninth Circuit case law to describe and apply the mechanics of extradition to this hypothetical in order to remain consistent with the subsequent analysis of the political offense exception. The court for the Southern District of Florida recently analyzed elements virtually identical to those used by the Ninth Circuit in deciding whether to allow the extradition of two American citizens to Bolivia. United States v. Fernandez-Morris, 99 F. Supp. 2d 1358, 1360 (S.D. Fla. 1999). 
that the fugitive committed the charged offenses; and (6) the alleged offenses are criminal in both Bolivia and the United States. ${ }^{81}$

In addition to the extradition requirements, the rule of non-inquiry will likely factor into Sánchez de Lozada's case. The rule addresses the potential argument that extradition should not be allowed because Bolivia's efforts to extradite Sánchez de Lozada are purely political. Under the rule of non-inquiry, an extradition court may not consider the political motivations of the requesting state (in this case, Bolivia) ${ }^{82}$ In examining the applicability of the rule, the "evaluations of the motivation behind a request for extradition so clearly implicate the conduct of this country's foreign relations as to be a matter better left to the Executive's discretion." ${ }^{\text {83 }}$ Therefore, the court in Sánchez de Lozada's ease likely will not consider Bolivia's motivations. Instead, the judge's determination will be based on whether Bolivia meets the requirements for extradition.

\section{B. The Requirements of Extradition Under the Bolivia-U.S. Extradition Treaty}

It is likely that Bolivia will be able to satisfy the first, second, and fourth elements of the extradition requirements just described. However, satisfying the remaining elements may prove more difficult for Bolivia. Each of these elements is analyzed in detail in the following Sections.

\section{Extraditable Crime Within the Treaty's Terms}

Article II of the 1995 Extradition Treaty between the United States and Bolivia states that an extraditable offense is one that is punishable under the laws of both Parties ${ }^{84}$ by a "deprivation of liberty for a maximum period of more than one year or by a more severe penalty." "Further, "[a]n attempt or conspiracy to commit, participation in, or association regarding the commission of an offense shall constitute an extraditable offense." 86

The first question is whether the offense with which Sánchez de Lozada is charged falls within the crimes included in the treaty. So far, the Bolivian Attorney General has indicted Sánchez de Lozada for genocide

81. In re Requested Extradition of Suarez-Mason, 694 F. Supp. 676, 676 (N.D. Cal. 1988).

82. See In re Extradition of Muhamed Sacirbegovic, 2005 U.S. Dist. LEXIS 707, at *60 (S.D.N.Y. Jan. I9, 2005).

83. Eain v. Wilkes, 641 F.2d 504, 5 I6 (7th Cir. 198 I); see also In re Locatelli, 468 F. Supp. 568, 575 (S.D.N.Y. 1979) (holding that the court eannot "look behind the charges as propounded by the Swiss Government and must, in this respect, yield this inquiry to the Seeretary of State"); Sindona v. Grant, 461 F. Supp. 199, 207 (S.D.N.Y. 1978) (holding that "the motives of the requesting country are not within the jurisdiction of the Court but are reserved for the province of the Secretary of State.").

84. This is known as the dual criminality requirement and is discussed in further detail in Part II.B.3, infra.

85. Extradition Treaty, supra note 2, art. 1I.1.

86. Id. art. II.4. 
"in the form of a bloody massacre." ditional charges of conspiracy to commit murder or attempted murder, those crimes would fall within the treaty's scope because they are punishable by a "deprivation of liberty for a maximum period of more than one year or by a more severe penalty. ${ }^{" 88}$ However, as discussed throughout this Part, the analysis becomes more complicated if Bolivia charges Sánchez de Lozada with genocide, only because such a crime may not carry the appropriate penalty or constitute an extraditable offense.

\section{Probable Cause}

Before a criminal suspect can be brought to trial, U.S. courts require that the government show there is probable cause to believe that the accused has committed the charged offense. ${ }^{89}$ To establish probable cause, there must be "evidence sufficient to cause a person of ordinary prudence and caution to conscientiously entertain a reasonable belief of the guilt of the accused." 90

Since Bolivia has yet to file an extradition request for Sánchez de Lozada, it is difficult to analyze whether the request will satisfy the probable cause requirement. A probable cause determination will be based on the evidence brought before the judge regarding the crimes that Sánchez de Lozada allegedly committed in Bolivia. ${ }^{91}$ At that time, Sánchez de Lozada can argue that the evidence does not demonstrate probable cause.

If Bolivia requests Sánchez de Lozada's extradition solely for the crime of genocide, establishing probable cause may be difficult because genocide is a specific intent crime. ${ }^{92}$ The U.N. Convention on the Prevention and Punishment of the Crime of Genocide defines the crime of genocide as follows:

any of the following acts committed with intent to destroy, in whole or in part, a national, ethnical, racial or religious group, as such: (a) Killing members of the group; (b) Causing serious bodily or mental harm to members of the group; (c) Deliberately inflicting on the group conditions of life calculated to bring about its physical destruction in whole or in part; (d) Imposing measures

87. Bolivia's Former President Charged With Genocide, supra note 6.

88. Extradition Treaty, supra note 2, art. II.1.

89. Quinn v. Robinson, 783 F.2d 776, 783 (9th Cir. 1986)

90. United States v. Femandez-Morris, 99 F. Supp. 2d 1358, 1365 (S.D. Fla. 1999); see also Gill v. Imundi, 747 F. Supp. 1028, 1038 (S.D.N.Y. 1990) ("Courts have long understood that the hearing before the extradition magistrate does not determine the guilt or innocence of the accused but rather represents a judgment whether there is competent evidence that would support a reasonable belief that the subject of the proceedings was guilty of the crimes charged.").

91. See Collins v. Loisel, 259 U.S. 309, 314-15 (1922).

92. Convention on the Prevention and Punishment of the Crime of Genocide, Dec. 9, 1948, 78 U.S.T.S. 278. 
intended to prevent births within the group; (e) Forcibly transferring children of the group to another group..$^{93}$

In cases involving genocide, international criminal tribunals have emphasized the intent requirement. Genocide has been described by these tribunals as being distinct from other crimes because "it embodies a special intent." $"$ Therefore, to meet the required probable cause showing for genocide, Bolivia must provide evidenee of intent, i.e., that Sánchez de Lozada intended to destroy the indigenous population, and that he specifically directed the military to use deadly force to that end. If Bolivia cannot demonstrate evidence of the special intent required for genocide, the nation will have to focus its efforts on establishing probable cause for conspiracy to commit murder or attempted murder.

\section{The Dual Criminality Requirement}

Under the dual criminality doctrine, the accused's offense must be considered criminal in both the requested and requesting nations. ${ }^{95}$ Extradition law "does not require that the name by which the crime is described in the two countries shall be the same.... It is enough if the particular act charged is criminal in both jurisdictions. ${ }^{p 96}$ Furthermore, the extradition treaty between the United States and Bolivia states that "it shall be irrelevant whether the laws in [the Requested] State place the offense within the same category of offenses, contain identical elements, or describe the offense by the same terminology as the laws in the Requesting State, so long as the underlying conduct is criminal in both States." 97

In this case, Bolivia will satisfy the dual criminality requirement if the extradition request charges Sánchez de Lozada with murder, attempted murder, or conspiracy to commit murder-all crimes under U.S. and Bolivian law. ${ }^{98}$ Bolivia may face difficulty, however, in showing dual criminality for the charge of genocide. Although the definition of genocide in the Bolivian criminal code closely tracks the definition found in the U.N. Convention on Genocide (which has been ratified by the United

93. Id.

94. Prosecutor v. Jean-Paul Akayesu, Case No. ICTR 96-T, Judgment, of 42 (Sept. 2, 1998), in Reisman, supra note 74, at 543; see also Prosecutor v. Radislav Krstic, Case No. IT-98-33-T, Judgment, ๆ 57I, (Aug. 2, 200I), in REISMAN, supra note 74, at 556.("[T] the characterization of genocide which encompasses only acts committed with the goal of destroying all or part of a group.") (emphasis in original).

95. Quinn v. Robinson, 783 F.2d 776, 783 (9th Cir. 1986).

96. Collins v. Loisel, 259 U.S. 309, 312 (1922).

97. Extradition Treaty, supra note 2, art. II.3(a); see also Letter of Submittal to the President, supra note 78 ("Inclusion of the dual-criminality clause without a list of specific offenses covered by the Treaty ... obviates the need to renegotiate or supplement the Treaty as offenses become punishable under the laws of both parties.").

98. See Código Penal [C.P] art. 25I (Bol.); see also 18 U.S.C. $\S 1117$ (2000) (conspiracy to murder), 18 U.S.C. § I1I3 (2000) (attempt to commit murder), 18 U.S.C. $\S$ IIII (2000) (murder). 
States), Bolivia goes further in including "bloody massacres" of the populace.$^{99}$ It is unclear whether the same intent is required for this offense as is required under the U.N. Convention on Genocide.

However, several circuit courts have held that the dual criminality requirement is satisfied when the country requesting extradition includes charges of murder or attempted murder in extradition requests involving war crimes. For example, in Demjanjuk v. Petrovsky, the Sixth Circuit held that the dual criminality requirement was met because murder "is clearly included in the offenses for which extradition is to be granted under the treaty" and that "the State of Israel has jurisdiction to punish for war crimes and crimes against humanity." ${ }^{100}$ Similarly, the Ninth Circuit allowed extradition in In re Extradition of Artukovic, where the accused was charged with war crimes, including murder. ${ }^{101}$ The court held that the murder charges satisfied the dual criminality requirement, although the charge of "war crimes" did not. ${ }^{102}$ In Sánchez de Lozada's case, if the court recognizes the crime of "genocide" as inclusive of multiple murders, the charge may satisfy the dual criminality requirement, especially since the United States has ratified the U.N. Convention on Genocide. ${ }^{103}$ Strategically, Bolivia's extradition request should include charges of murder, attempted murder, or conspiracy to commit murder to avoid the problems involved with charging genocide alone.

\section{A Bolivian Extradition Case}

To illustrate the above concepts, a recent extradition case involving Bolivia proves helpful. In United States v. Fernandez-Morris, the District Court for the Southern District of Florida held that two American citizens were not extraditable to Bolivia because Bolivia failed to show probable cause and because dual criminality did not exist. ${ }^{104}$ The two defendants had been involved in a complicated business partnership in Bolivia with a Bolivian citizen. ${ }^{105}$ When the partnership disintegrated, the Bolivian citizen filed a criminal complaint against the defendants and their family members, claiming fraud and other illegal activities. ${ }^{106}$ Thereafter a Bolivian

\footnotetext{
99. See Código Penal [C.P] art. 138 (Bol.).

100. 776 F.2d 571, 583 (6th Cir. 1985).

101. 628 F. Supp. 1370 (C.D. Cal. 1986), overruled on other grounds, Lopez-Smith v. Hood, 121 F.3d 1322 (9th Cir. 1997).

102. Id.

103. See Convention on the Prevention and Punishment of the Crime of Genocide, supra note 92. Bolivia, however, is not a signatory to the treaty.

104. 99 F. Supp. 2d 1358, 1373 (S.D. Fla. 1999). However, the court recognized that "extradition treaties are to be liberally construed so as to effect their purpose, that is, to surrender fugitives for trial for their alleged offenses." Id. at 1360.

105. Id. at 1363 .

106. Id.
} 
judge found the defendants guilty of "fraud, illegal association, and breach of trust," sentencing them in absentia to seven years in prison. ${ }^{107}$

The district court stated that because the defendants were convicted in absentia, the "conviction is only considered a charge of a crime rather than a conviction for the purposes of . . probable cause." 108 Furthermore, the court found that the evidence did not satisfy the probable cause requirement. ${ }^{109}$ Instead, the court found that the complainant's affidavit and the summary of the proceedings before the Bolivian judge were merely speculative and conclusory, with no evidence to suggest that the defendants held the criminal intent required to commit fraud. ${ }^{110}$ In addition, the district court held that Bolivia failed to meet the dual criminality requirement because the evidence pointed more toward civil liability than the commission of a crime. ${ }^{111}$ Even if the complainant could bring a criminal case under Bolivian law, the court doubted that the defendant's actions constituted criminal conduct under U.S. law. In the United States, "certain unethical business conduct does not rise to the level of criminally fraudulent behavior." 112

Fernandez-Morris provides insight into how a court might analyze Bolivia's request for extraditing Sánchez de Lozada. Bolivia's evidence must be sufficient to show probable cause, and the dual criminality requirement must be met regarding the alleged crimes. Therefore, Bolivia must be careful to charge Sánchez de Lozada with crimes that are criminal in both the United States and Bolivia. Rather than seeking extradition only for the crime of genocide, Bolivia should include the crimes of murder, attempted murder, or conspiracy to commit murder-crimes that are more clearly recognized in the United States. Fernandez-Morris also seems to counsel against trying Sánchez de Lozada in absentia in Bolivia because the U.S. court would still retain authority to review all the facts in evidence, regardless of whether there is a conviction in a Bolivian court.

\section{The Possibility of an Executive Remedy}

Sánchez de Lozada, however, may have an extra-legal remedy, one outside the normal judicial process but well within the executive's established powers. Due to U.S. support of Sánchez de Lozada's presidency, as well as Sánchez de Lozada's reciprocal support of U.S. policies, the former

107. Id. at 1360 .

108. Id. at 1365. Probable cause "is not established merely by the fact that there has been an in absentia conviction. Rather, in those cases, the court 'must scrutinize the evidence carefully to determine at least a reasonable probability that the petitioner is guilty of the crime."' Id. at 1366 . (quoting United States ex rel. Argento v. Jacobs, 176 F. Supp. 877, 883 (N.D. Ohio 1959)).

109. Fernandez-Morris, 99 F. Supp. 2d at 1368-69.

110 . Id. at 1369 .

111. Id.

112. Id. 
Bolivian leader may petition the Secretary of Statc for a stay of extradition. ${ }^{113}$ If this stay is granted, Sánchez de Lozada's extradition proceedings would end, he would remain in the United States, and the result of any judicial process cffectively would be nullified.

The executive retains the sovereign right to use his discretion to deny extradition even when the legal requirements have been fulfilled. Nonetheless, evaluating the legality of extraditing Sánchez de Lozada and considering the applicability of the political offense exception address an issue of legal significance. Sánchez de Lozada's situation is noteworthy because it illustrates the difficulties that arise when extradition proceedings are initiatcd against former government officials living in exile in the United States. The important question remains whether Sánchez de Lozada and similar actors shouId be extradited to face their alleged crimes. If extradition is deemed appropriate, the next question is whether Sánchez de Lozada and other former government officials can use the political offense exception as a defense to extradition.

III

\section{Legal Background of the Political Offense Exception}

\section{A. The Development of the Political Offense Exception}

\section{Historical Context}

In its current form, the political offense exception offers a defense to extradition for actors who commit crimes of a political nature in the contcxt of a political struggle. The exception provides that these actors should not be extradited as though they had committed ordinary crimes and fled the country to avoid being brought to justice.

The political offense exception originated from the French and Amcrican revolutions. It developed from the concept of "justified political resistance," which was central to the revolutionary ideologies of the time, which, in turn, were grounded "in a belief that individuals have a 'right to resort to political activism to foster political change."'114 The original

113. See 18 U.S.C. $\S 3186$ (2000) ("The Secretary of State may order the person committed under sections 3184 or 3185 of this titlc to be delivered to any authorized agent of such forcign government, to be tried for the offense of which charged. Such agent may hold such person in custody, and take him to the territory of such foreign government, pursuant to such treaty. A person so accused who escapes may be retaken in the same manner as any person accused of any offense."). This executive action would not be without its own consequences, however, as addresscd in Part V, infra

114. Quinn v. Robinson, 783 F.2d 776, 793 (9th Cir. 1986) (quoting Cindy Verne Schlaefer, Note, American Courts and Modern Terrorism: The Politics of Extradition, I3 N.Y.U. J. INT'L L. \& PoL. 617, 622 (1981)); see also M. Cherif Bassiouni, The Political Offense Exception in Extradition Law and Practice, in International Terrorism and Political Crimes 400 (M. Cherif Bassiouni ed., 1975) ("The history of the political offense exception is inexorably linked to the rise of eighteenth century political theories on freedom and democracy."). See generally Michael Littenberg, Comment, The Political Offense Exception: An Historical Analysis and Model for the Future, 64 TUL. L. REV. I1 196 (I990). 
justification for the exception centered on the concern that unsuccessful revolutionaries or rebels "should not be returned to countries where they may be subjected to unfair trials and punishments because of their political opinions." 115 In addition, the exception mirrored the prevailing concept that governments "should not intervene in the internal political struggles of other nations." "16 In fact, one of the main reasons for the exception was that it permitted the requested state to "remain aloof from the internal affairs of the requesting state." 117 However, although nations would prefer to remain "aloof," this approach often reflects preexisting judgments about the requesting state's capacity for judicial fairness. ${ }^{118}$

Codified by Belgium in 1833, the political offense exception was part of the first recorded extradition act in history. ${ }^{119}$ France began to incorporate the exception in its treaties later in 1833, followed by the United States in 1843 and England in $1852 .{ }^{120}$ National laws incorporated these concepts by the mid-1850s. By the end of the nineteenth century, the political offense exception had become part of international law. ${ }^{121}$

\section{The Nature of a Political Offense}

Courts almost uniformly recognize two distinct categories of political offenses: "pure" political offenses and "relative" political offenses. ${ }^{122}$ Pure political offenses are those directed against the government or governing political organization, such as treason, sedition, and espionage, which do not involve the commission of common crimes or injury to private

115. Quinn, 783 F.2d at 793; see also Bassiouni, supra note 114, at 444 . ("The reasons for the political offense exception rest in part upon the asylum state's sense of humane treatment and belief in human rights and personal and political freedom. Furthermore, it is generally acknowledged that political crimes affect the demanding state's most sensitive interests, and, therefore, inspire a passionately hostilc atmosphere which makes an orderly and fair trial very difficult.").

116. Quinn, 783 F.2d at 793; see also VAN DEN WIJNGAERT, supra note 3, at 3, 18.

117. Geoff Gilbert, Transnational Fugitive OfFenders in International Law 204 (1998).

118. Id. The exception "mixes inseparably the humanitarian concem for the fugitive on the one hand and on the other the politically motivated unwillingness of the requested State to get involved in the international political affairs of the requesting State." Id. (internal citations omitted).

119. VAN DEN WIJNGAERT, supra note 3 , at 12.

120. Id. at 13. Belgium enactcd legislation in 1833 to incorporate the political offense exeeption in its extradition practices. France and Switzerland enacted legislation in 1834, followed by England in 1870. Although the exception is incorporated into U.S. extradition treatics, there is no speeific U.S. legislation enacting the exception. Bassiouni, supra note 114 , at 401.

121. Quinn, 783 F.2d at 793. However, at least one scholar asserts that the political offense exception has not risen to the level of customary law because not all extradition treaties include the exception. Notably, the states of the former Soviet bloc did not include the exemption in their treaties. See GILBERT, supra note 117 , at 213.

122. Quinn, 783 F.2d at 793; VAN DEN WIJNGAERT, supra note 3, at 106. 
individuals. ${ }^{123}$ Courts seldom deal with pure political offenses because most treaties specifically exclude them from extraditable crimes. ${ }^{124}$

In contrast, a relative political offense is a common crime pursued with a political purpose, or "because the act had political consequences or was situated in a political context." ${ }^{\text {"25 }}$ Because these common crimes often include civilian death or injury, most disagreements over the political offense exception involve relative political offenses. Many have argued that the political offense exception should not apply in cases of civilian death or injury, no matter how politically motivated the crime. ${ }^{126}$ Similarly, some scholars argue that the exception has been overextended to include too many categories of fugitives, including terrorists; this result was not contemplated by the original formulations of the exception. ${ }^{127}$ Thus, some courts limit the use of the exception when violent acts are directed toward civilians. ${ }^{128}$

Courts in different countries have developed various tests for determining whether "the nexus between the crime and the political act is sufficiently close for the crime to be deemed not extraditable." 129 These tests fall within three main categories: the Swiss "proportionality" or "predominance" test, the French "objective" test, and the Anglo-American "incidence" test. ${ }^{130}$ The most widely accepted approach by academics-the Swiss approach -incorporates an independent test of proportionality that includes a balancing between the political and common elements of the crime. ${ }^{131}$ If the crime is violent, "then the common element will outweigh the political motive unless such violence is the only means of achieving the

123. Quinn, 783 F.2d at 793; VAN DEN WIJNGAERT, supra note 3, at 106 . "Pure" political offenses are also called "purely" or "absolute" political offenses.

124. Quinn, 783 F.2d at 793; see also Satya DeVa Bedi, Extradition In INTERNational LaW AND PRACTICE 181 (1966) ("The concept of purely political offences is generally agreed upon and causes no problem. They are the offences against the security of the state ... because they lack the essential elements of the ordinary crime ...").

125. "Relative" offenses are also called "mixed," "related," and "complex" political offenses. See VAN DEN WIJNGAERT, supra note 3, at 108; Quinn, 783 F. 2 d at 794; see also BEDI, supra note 124, at 182 ("[W]hen a common offence is perpetrated with a political motive, it acquires the character of a relative political offence.").

126. See text accompanying note 1, supra.

127. GILBERT, supra note 117, at 245, 246-268; see also VAN DEN WIJNGAERT, supra note 3, at 197 ("[T] serious crimes, which, although committed for political reasons, are so dangerous and detrimental to international public order that extradition should not be excluded, simply because of their being politically motivated. On the other hand, the political offence exception has proved to be too narrow because it does not directly protect common offenders who, if extradited, would risk an unfair trial in the requesting state.").

128. See generally Eain v. Wilkes, 641 F.2d 504 (7th Cir. 1981); In re Extradition of Atta, 706 F. Supp. 1032 (E.D.N.Y. 1989).

129. Quinn, 783 F.2d at 794.

130. Id.; see also Bassiouni, supra note 114, at 412-30.

131. GILBERT, supra note 117 , at 234. 
end."132 As discussed later in this Comment, using the proportionality test instead of the incidence test may solve some of the problems of allowing former government officials to use the political offense exception.

\section{B. The "Incidence" Test}

The Anglo-American "incidence" test was first described by the British Divisional Court in In re Castioni, ${ }^{133}$ a case in which the Swiss government requested the extradition of a Swiss citizen from Great Britain for storming the palace gates and killing a government official. ${ }^{134}$ The British Court refused to grant extradition, finding that the accused's actions were "incidental to and formed a part of political disturbances." court held that "common crimes committed 'in the course' and 'in the furtherance' of a political disturbance would be treated as political offenses." 136

In the United States, political offense jurisprudence began with the seminal case In re Ezeta, decided in I894. ${ }^{137}$ After a successful revolutionary takeover in El Salvador, the new government requested the extradition of several former members of the military, including General Ezeta, the brother of the ousted president. ${ }^{138}$ The individuals were charged with committing murder and robbery while attempting to suppress the revolution. ${ }^{139}$ The Ninth Circuit held that all of the individuals, save one, ${ }^{140}$ were not extraditable because the crimes were "committed during the progress of actual hostilities between the contending forces."141 Furthermore, the "accused were engaged as military officers under the government, acting

132. Id. at 235 .

133. In re Castioni, 1 Q.B. 149 (1890); Quinn, 783 F.2d at 795.

134. Quinn, 783 F.2d at 795.

135. Id. at 796 (quoting In re Castioni, 1 Q.B. at 166).

136. Quinn, 783 F.2d at 796 (quoting In re Castioni, 1 Q.B. at 156). After In re Castioni, the interpretation of the incidence test developed differently in the United States and Great Britain. Id. In Great Britain, to avoid extradition, the political disturbance must bc a valid attempt to effect governmental change, thus requiring a judgment about the attempt's "validity." GILBERT, supra note 117, at 219-20. Additionally, the British test incorporates an element of proportionality. Courts ask whether there is a "sufficiently close and direct link between the crime and the organization's goal." Further, they examine the means used in committing the offense and whether the offense is directed at a government or military target or civilians. Id. at 221. More recently, Great Britain has limited the use of the political offense exception by treaty. $I d$. at 225 . The 1986 Anglo-U.S. Supplementary Extradition Treaty and the Anglo-lndian Extradition Treaty allow the British government to exclude specific crimes as nonpolitical. Id.

137. 62 F. 972 (N.D. Cal. 1894).

138. Id. at 977 .

139. Id. at 980 .

140. One former military official was not extraditable becausc he allegedly committed the murder four months before the revolution began, and therefore his act was "free from any political aspect." Id. at 986 .

141. Id. at 997 . 
against revolutionary forces in the field [and] the crimes or offenses were therefore of a political character." 142

Two years later, the U.S. Supreme Court decided Ornelas v. Ruiz, its sole case directly addressing the political offense exception. ${ }^{143}$ In Ornelas, three individuals were charged with crimes stemming from a raid by a large band of armed men on a Mexican village near the Texas border. ${ }^{144}$ The men were charged with murder, arson, robbery, and kidnapping. ${ }^{145}$ Citing In re Castioni and In re Ezeta, the Court held that the group could not assert the political offense exception as a defense to extradition. ${ }^{146}$ The Court listed four relevant factors in its analysis of the application of the political offense exception: (1) the character of the foray, (2) the mode of attack, (3) the persons killed or captured, and (4) the kind of property taken or destroyed ${ }^{147}$ Applying these factors, the Court found that although the raid occurred at approximately the same time as a revolutionary movement, the raid did not relate to the movement and was not political in nature. ${ }^{148}$

Since In re Ezeta and Ornelas, courts have continued to refine the incidence test. ${ }^{149}$ Due to the limited Supreme Court precedent, courts have looked to various circuit court cases for guidance. ${ }^{150}$ The Ninth Circuit's case law has been particularly influential in interpreting the political offense exception. ${ }^{151}$ The court's formulation of the incidence test requires "(1) the occurrence of an uprising or other violent political disturbance at

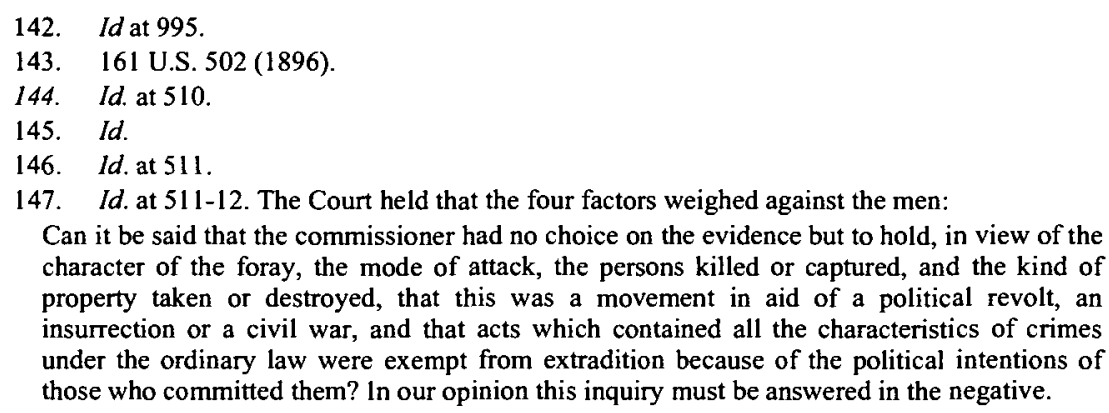
character of the foray, the mode of attack, the persons killed or captured, and the kind of property taken or destroyed, that this was a movement in aid of a political revolt, an insurrection or a civil war, and that acts which contained all the characteristics of crimes under the ordinary law were exempt from extradition because of the political intentions of those who committed them? In our opinion this inquiry must be answered in the negative.

148. Id. (quoting a statement of the Secretary of State: "The idea that these acts were perpetrated with bona fide political or revolutionary designs is negatived by the fact that immediately after this occurrence, though no superior armed force of the Mexican government was in the vicinity to hinder their advance into the country, the bandits withdrew with their booty across the river into Texas.").

149. Quinn v. Robinson, 783 F.2d 776, 797 (9th Cir. 1986).

150. Ornelas, 161 U.S. at 502.

151. This Comment will use the influential Quinn case and Ninth Circuit case law as a framework through which to analyze whether Sánchez de Lozada can and should use the political offense exception. The author acknowledges that the Eleventh Circuit is not bound by Ninth Cireuit case law. However, the comprehensiveness of the Ninth Circuit's case law may influence the Eleventh Circuit's reasoning. 
the time of the charged offense, and (2) a charged offense that is 'incidental to,' 'in the course of,' or 'in furtherance of' the uprising." 152

In Quinn, a U.S. citizen and member of the Provisional 1rish Republican Army was charged with murder and conspiring to cause explosions in London. ${ }^{153}$ The Ninth Circuit agreed with the district court judge's findings on the "incidental to" prong of the test and held that the crimes would be "incidental to" an "uprising" if an uprising existed at the site of the attacks. ${ }^{154}$ Although the Ninth Circuit found that an uprising existed in Northern lreland at the time of the bombings, the political unrest did not extend to England, where the bombings occurred. ${ }^{155}$ Quinn was extraditable to Great Britain to stand trial because the "uprising" prong was not met. ${ }^{156}$

The Quinn court comprehensively analyzed the use of the political offense exception with respect to its continued relevance in the twentieth century and beyond. ${ }^{157}$ Quinn was decided in the late 1980s, when the political offense exception was criticized for being both under-inclusive and over-inclusive, as well as for being unable to adequately address the realities of international terrorism. ${ }^{158}$ ln response to such criticism, the court maintained that the incidence test "has served us well and requires no significant modification." 159 The test "(a) protects acts of domestic violence in connection with a struggle for political self-determination, but (b) was not intended to and does not protect acts of international terrorism." 160 However, since Quinn, the United States has revised the political offense exception clause in its extradition treaties (as with Bolivia) to explicitly exclude acts of terrorism and other international crimes. ${ }^{161}$

Further, the Quinn court clarified the "uprising" and "incidental to" components of the incidence test to impose spatial and temporal limitations on the application of the political offense exception. In describing the

152. Quinn, 783 F.2d at 797.

153. Id. at 793 .

154. Id. at 811 .

155. Id. at 813 .

156. Id. at 818 .

157. Id.

158. See, e.g., GlLBERT, supra note 117, at 207 ('The very term 'political offencc' should have forewarned the nineteenth century drafters of the impending conflicts and disputes, because for evcry ten people there will always be at least ten different interpretations of 'politics."').

159. Quinn, 783 F.2d at 806 ("The growing problem of international terrorism, serious as it is, does not compel us to reconsider or redefine that test. The test we havc used since the 1800 's simply does not cover aets of international terrorism.").

160. Id.

161. Extradition Treaty, supra note 2, art. V. Article V provides that "offenses as to which there is an obligation to establish criminal jurisdiction pursuant to multilateral international treaties in force with respect to the Parties" are not considered political offenses. Id. Offenses eovered by multilateral international treaties include aircraft hijacking and narcotics trafficking. Letter of Submittal to the President, supra note 78. 
parameters of "uprising," the court stated that the exception is "applicable only when a certain level of violence exists and when those engaged in that violence are seeking to accomplish a particular objective." 162 Furthermore, the term "refers to a revolt by indigenous people against their own government or an occupying power."163 This description limits the uprising to a geographical area, effectively excluding international terrorist activities because those actors commit crimes beyond the boundaries of their home nations.

In meeting the requiremcnt that the offense be "incidental to" the uprising, the court held that the offense must be causally or ideologically related to the uprising. ${ }^{164}$ In other words, there must be a nexus between the act and the uprising, although the nexus should be liberally construed. Under the liberal nexus standard, "neither proof of the potential or actual effectiveness of the actions in achieving the group's political ends, nor proof of the motive of the accused or the requesting nation is required."165 In addition, the court rejected the distinction made by the courts in Eain $v$. Wilkes $^{166}$ and In re Doherty ${ }^{167}$ that crimes against civilians should be excluded from the application of the political offense exception. ${ }^{168}$ Instead, the court determined that it should remain ideologically neutral when applying the test and refrain from judging the effectiveness or acceptability of revolutionary tactics. ${ }^{169}$

A recent district court case held that a First Nations ${ }^{170}$ man was permitted to invoke the political offense exception against a Canadian extradition request. ${ }^{171}$ The federal court for the District of Oregon found that the accused's alleged offenses met the incidence test because they were incidental to a tribal uprising against the Canadian government regarding a longstanding land dispute. ${ }^{172}$ The district court followed the Ninth Circuit's holding in Quinn that the "incidental to" requirement " must be applied in an objective, non-judgmental manner' and may include attacks on civilian targets." 173

However, the "incidental to" requirement came under attack in a recent Ninth Circuit case addressing the political offense exception. In

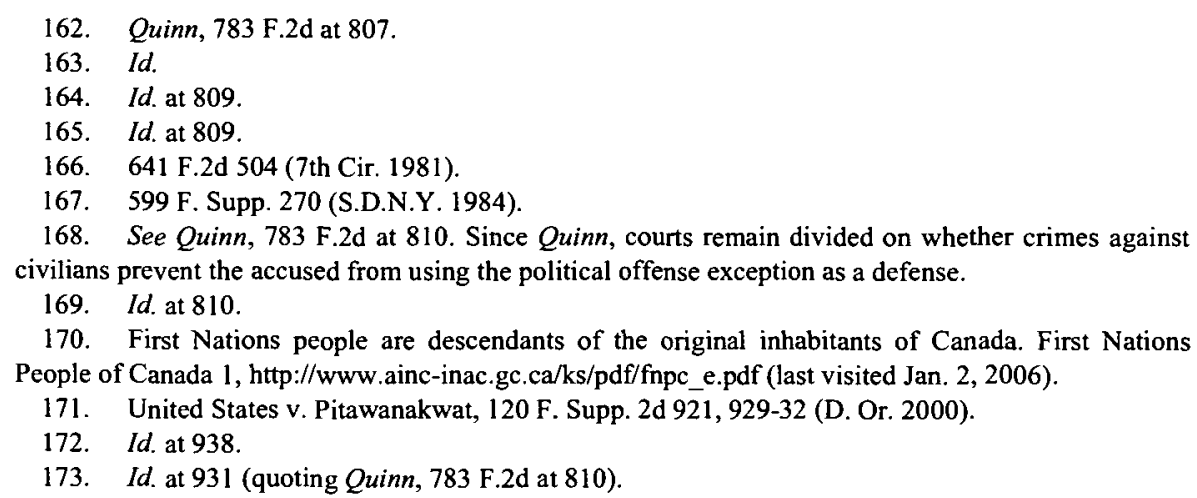


Barapind v. Enomoto, the extradition court dismissed Quinn's discussion of the "incidental to" prong as dicta and declined to adopt this "uncivilized standard" because Barapind, a Sikh insurgent, allegedly had killed Indian civilians during a period of frequent clashes between Sikhs and the Indian government. ${ }^{174}$ Instead, the court followed the Seventh Circuit's approach in Eain and held that the "indiscriminate killings of civilians ... cannot and must not qualify for the political offense exception to extradition, even if "politically motivated." "175 Barapind later was vacated, and the Ninth Circuit, sitting en banc, reaffirmed the second prong of the incidence test. ${ }^{176}$ The en banc court held that the extradition court "erred in concluding that it was not required to follow Quinn" and confirmed that the Quinn articulation of the "incidental to" prong was the law of the circuit. ${ }^{177}$ The court remanded the case for consideration of the applicability of the Quinn analysis of the exception to the alleged crimes. ${ }^{178}$ Thus, both prongs of the incidence test continue to be well grounded in Ninth Circuit jurisprudence.

\section{IV \\ Applying the Political Offense Exception to Former GovernmENT OfFICIALS}

\section{A. Quinn v. Robinson}

In the portion of its opinion detailing the case history and purpose for the political offense exception, the Quinn court analyzed the use of the exception by actors more similar to Sánchez de Lozada than William Joseph Quinn. ${ }^{179}$ First, the court held that crimes against humanity, such as genocide, extermination, enslavement, and other violations of international law, are wholly excluded from the political offense exception. ${ }^{180}$ The court stated, "[W]e do not believe that the political offense exception, even if meant to protect the acts of representatives of a former government, should [be] extended to protect those carrying out a governmental policy calling for acts of destruction whose nature and scope... exceeded human imagination." $" 181$

174. 360 F.3d 1061, 1075 (9th Cir. 2004), rev'd in part by 400 F.3d 744 (9th Cir. 2005) (en banc) ("We agree with the magistrate that the political offense exception is inapplicable to shield the knowing effort to kill or injure unarmed, uninvolved, innocent civilians who are non-combatants in the struggle." (quoting In re Extradition of Singh, 170 F. Supp. 2d 982, 1036 (E.D. Cal. 2001)).

175. Barapind, $360 F .3 d$ at 1077.

176. Id. at 751 .

177. Id.

178. Id. at 753 .

179. Whereas Quinn allegedly committed crimes against the British government, Sánchez de Lozada was part of the govemment and allegedly used his executive office to suppress an uprising.

180. See Quinn, 783 F.2d at 800 . This line of reasoning followed the findings of the Nuremberg Trials conducted by the International Military Tribunal.

181. Id. at 800-01 (citations and intemal quotations omitted). 
Of consequence to Sánchez de Lozada's case, the Ninth Circuit questioned whether the political offense exception is applicable to former government officials, ${ }^{182}$ because the original intent of the exception was to protect individuals engaged in political resistance. ${ }^{183}$ The court noted that the exception is based on several policy reasons, including the "concern about the safety and welfare of those who have engaged in political activity that is offensive to the government now in power and a commitment to non-intervention in the internal affairs of foreign countries." 184 These policy rationales potentially could be applied to former government officials who have fled their native countries. ${ }^{185}$

Though the political offense exception theoretically may be applicable to cases involving former government officials, courts have questioned whether the incidence test is an appropriate means for evaluating whether these ex-officials can be extradited. ${ }^{186}$ Even in the seminal case of In re Ezeta, the district court recognized that most extradition cases involve acts committed against the government, and thus these precedents are of limited value where the case involves former representatives of an existing government. ${ }^{187}$ The Ninth Circuit in Quinn further acknowledged that courts have had few occasions to analyze the applicability of the political offense exception to former government officials. ${ }^{188}$ The court surmised,

Because all acts of governmental officials that carry out a government policy are, by definition, political, applying the incidence test makes little sense and leads to paradoxical results. It gives special protection to officials when they are suppressing an uprising and strips them of protection at all other times. |Conceptually, the appropriate analogy to individuals acting in furtherance of an uprising is government officials acting in furtherance of a government policy, not in connection with an uprising. Thus, a serious question exists as to whether we should apply the incidence test where extradition is requested of persons who commit crimes while officials of a government. ${ }^{189}$

\section{B. In re Suarez-Mason}

Two years after Quinn was decided, the federal court for the Northern District of California addressed the political offense exception's application to former government officials in In re Suarez-Mason. ${ }^{190}$ In this case,

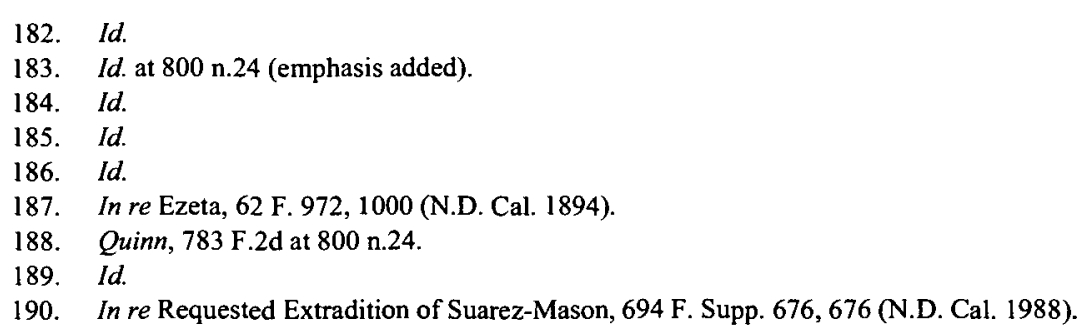


Argentina sought the extradition of a former general, Carlos Guillermo Suarez-Mason, who was involved in the military junta that terrorized Argentina from 1976 to 1979. Argentina charged the general with fortythree counts of murder and twenty-four counts of "unlawful deprivation of freedom."191 The district court recognized that where the political offense exception has been invoked by a former government official whose alleged violations occurred while suppressing a rebellion, the law enters "largely uncharted territory. $" 192$

After deciding that Argentina had made the necessary showing to warrant Suarez-Mason's extradition for murder, the court faced two issues in determining whether he could assert the political offense exception. ${ }^{193}$ First, the court addressed "whether the exception may be relied upon by a former government official," and second, "if so, what test is to be applied in determining whether the former official's actions fall" within the exception. ${ }^{194}$

In deciding these issues, the court declined to extend the protection of the political offense exception to former government officials for three reasons. First, the "extension would directly contravene the primary rationale for the exception-that of protecting acts of rebellion against oppressive rule." 195 Second, "it does not follow that such officials should be protected from being justly called to account for their illegal actions undertaken while in power."196 Third, it is "misleading to characterize the exception as founded upon [a] commitment to nonintervention in the internal affairs of foreign countries. $" 197$

However, consistent with the Ninth Circuit's statement that the issue remained open, ${ }^{198}$ the court continued to analyze whether Suarez-Mason could successfully invoke the political offense exception using the incidence test. ${ }^{199}$ The court held that Suarez-Mason could not use the exception as a defense because he did not satisfy both prongs of the test. ${ }^{200}$ Although he established the existence of an uprising in Argentina, he failed to

191. Id. at 679. Suarez-Mason was a military commander in the Argentinian army with responsibility for a geographical zone containing seven million people. An estimated 5,000 people disappeared from his zone during his tenure. $I d$. at 683 .

192. Id. at 703 .

193. Id. at 702-03.

194. Id. at 703 .

195. Id. at 704 .

196. Id.

197. Id. at 705 .

198. In Quinn, the Ninth Circuit reserved the question of "whether offenses committed by government officials or in connection with wars between nations are covered by the exception and, if so, whether a different test would be appropriate." 783 F.2d at 817.

199. In re Requested Extradition of Suarez-Mason, 694 F. Supp. 676, 705 (N.D. Cal. I988) (citing three other cases involving former government officials in which courts applied the incidence test without analyzing the appropriateness of its application to the conduet of government actors).

200. Id. at 707 . 
establish that the alleged murders were "incidental to" to the uprising. ${ }^{201}$ Because Suarez-Mason submitted no evidence that the victims were participants in any "violent or revolutionary activity," there was no "rational nexus between the homicides and any uprising which may have been occurring." 202

\section{Extradition of Former Government Officials for Financial Crimes}

An interesting aspect of the law surrounding the political offense exception concerns extradition for financial crimes and fraud. Not surprisingly, whether former government officials may use the political offense exception to avoid extradition for financial crimes committed in their home countries is a more settled area of the law than whether they can be extradited for violent crimes. Even when it involves political corruption, financial fraud by government officials "traditionally has been considered outside the 'political offense' exception."203

The Fifth Circuit has visited this question in two main cases: Jimenez v. Aristeguiet ${ }^{204}$ and Garcia-Guillern v. United States. ${ }^{205}$ In the early 1960 s, Venezuela sought the extradition of Marcos Perez Jimenez, a former president who was then residing in Miami, Florida. ${ }^{206}$ Although Venezuela attempted to extradite Jimenez to face murder charges, the district court found that there was not enough evidence to establish probable cause for those crimes. ${ }^{207}$ However, Venezuela succeeded in extraditing Jimenez because the Fifth Circuit upheld the lower court's finding of probable cause for various financial crimes allegedly committed while Jimenez held office ${ }^{208}$ Although Jimenez argued that the financial crimes were of a political character, the court found no evidence that the crimes "were committed in the course of and incidentally to a revolutionary uprising or other violent political disturbance."209

ln another case, Peru sought the extradition of its former director general of the Ministry of Education, Jose Miguel Garcia-Guillern, for financial crimes. ${ }^{210}$ The Fifth Circuit found that the evidence submitted by Peru indicated probable cause for the crime of embezzlement by a public officer

\footnotetext{
201. Id.

202. Id.

203. Koskotas v. Roche, 931 F.2d 169, 172 (1st Cir. 1991); see also Sindona v. Grant, 619 F.2d 167,173 (2d Cir. 1980) (holding that fraudulent banknuptcy committed against the ltalian government is not a political offense); Jhirad v. Ferrandina, 536 F.2d 478, 485 (2d Cir. 1976) (holding that embezzlement by a former Indian Navy official is not a political offense).

204. 311 F.2d 547, 560 (5th Cir. 1962).

205. 450 F.2d 1189, 1192 (5th Cir. 1971).

206. Jimenez, 311 F.2d at 551 .

207. Id.

208. Id.

209. Id. at 560 .

210. Garcia-Guillern, 450 F.2d at 1191 .
} 
and granted extradition. ${ }^{211}$ Garcia-Guillern's attempt to use the political offense exception failed because the court applied the incidence test to his alleged crimes and found that they did not fall within the political offense exception, as they had not been committed "in the course of or incidental to an "uprising." "'12

The cases involving the extradition of former government officials for financial crimes illustrate the concerns of the Ninth Circuit in Quinn and the district court in Suarez-Mason. Where the case involves financial crimes, it is clear that allowing officials to invoke the political offense exception is inappropriate and that the incidence test is unhelpful. The facts of Jimenez and Garcia-Guillern indicate that financial crimes do not fit within the incidence test because the crimes are not in furtherance of a popular uprising against an oppressive government; rather, they are actions in pursuit of personal gain. In fact, the government officials in SuarezMason, Garcia-Guillern, and Jimenez were able to commit their crimes precisely because they were part of oppressive governments.

\section{The Appropriateness of Applying the Political Offense Exception to Former Government Officials}

The appropriateness of allowing former government officials to use the political offense exception to extradition is a complicated question. Like other citizens, former officials face the possibility of persecution for their political opinions instead of or in addition to being prosecuted for their common law crimes. The Ninth Circuit has asserted that the political offense exception, in addition to protecting participants in rebellions, might serve other purposes that justify former government officials' use of the exception, including preventing former officials from facing unfair trials and punishment under new governments. ${ }^{213}$ Additionally, the exception might protect a former official forced to use violence to establish order or to prevent an undemocratic coup d'etat.

However, it is unclear whether most former government officials would be wholly dependent upon the political offense exception to avoid unjust extradition. To avoid extradition, a former government official could seek asylum status, obtain relief from deportation under the U.N. Convention Against Torture, ${ }^{214}$ or petition the Secretary of State for a stay of extradition. Further, it is doubtful whether allowing former government officials to use the exeeption was contemplated in the original purpose of the exception, and courts question the usefulness of the political offense

211. Id.

212. Id. at 1192

213. Quinn, 783 F.2d at 800 n.24; In re Requested Extradition of Suarez-Mason, 694 F. Supp. 676, 704 (N.D. Cal. 1988).

214. Convention Against Torture and Other Cruel, Inhuman or Degrading Treatment or Punishment, G.A. Res. 39/46, U.N. Doc. A/39/51 (Dec. 10, 1984). 
exception in such circumstances. ${ }^{215}$ The whole framework and test used to apply the political offense exception has been built around the situation of rebels who commit violent acts in protest against their governments. Lacking the resources of a nation, rebels must show a court that their actions are political in order to avoid extradition. In sharp contrast, every act a government official performs is arguably political, and officials are ablc to act precisely because they hold positions of power. Under current political exception jurisprudence, all former officials need to demonstrate is that some sort of uprising exists.

As the following discussion of Sánchez de Lozada's situation will illustrate, the use of the political offense exception as currently applied by U.S. courts has a paradoxical and perverse result. If actors such as Sánchez de Lozada can readily use the exception as a defense, then the exception should not apply to government officials in total, or a new test must be developed. This new test must be responsive to the unique circumstance of the former government official.

\section{E. The Political Offense Exception as Applied to Sánchez de Lozada}

This Section applies the political offense exception to Sánchez de Lozada by examining the relevant provisions of the extradition treaty between the United States and Bolivia, reviewing the applicable case law, and determining whether Sánchez de Lozada can satisfy the requirements of the incidence test.

The analysis of the political offense exception in an extradition case depends heavily on the language of the specific treaty. ${ }^{216}$ In this case, the applicable language in the U.S.-Bolivia Extradition Treaty is found in article V, Bases for Non-Discretionary Denial of Extradition. According to the provision, "Extradition shall not be granted if the offense for which extradition is requested is a political offense."217

Bccause of the difficulties in satisfying the requirements of probable cause and dual criminality with respect to genocide, it is unclear whether Sánchez de Lozada will be able to use the political offense exception where the extradition request is based solely on a genocide charge. ${ }^{218}$ Therefore, it is critical to analyze whether the political offense exception applies to ordinary criminal charges against Sánchez de Lozada and similarly situated government officials. If Bolivia brings charges other than genocide against Sánchez de Lozada, he will bear the initial burden of proof in establishing the essential elements of the political offense exception. ${ }^{219}$ Once

\footnotetext{
215. Suarez-Mason, 694 F. Supp. at 704.

216. McMullen v. INS, 788 F.2d 591, 596 (9th Cir. 1986).

217. Extradition Treaty, supra note 2, art. V.

218. See supra notes 92-103 and accompanying text.

219. United States v. Pitawanakwat, 120 F. Supp. 2d 921, 928 (D. Or. 2000).
} 
established, the burden then shifts to Bolivia (the requesting state) to prove that the alleged crimes are not of a political character. ${ }^{220}$ Under the rule of speciality, if extradited, Sánchez de Lozada cannot be charged or convicted of crimes not included in the offenses for which extradition was granted. ${ }^{221}$

Of the cases discussed in this Comment, Suarez-Mason is the most factually analogous to Sánchez de Lozada's case. Thus, the district court's reasoning is helpful in determining whether Sánchez de Lozada would be able to invoke the political offense exception. Sánchez de Lozada and Suarez-Mason both served as heads of state responsible for police and military operations. ${ }^{222}$ Another possible similarity, depending on Bolivia's extradition request, is that Suarez-Mason was not charged with personally committing the murders. ${ }^{223}$ Instead, he was charged "as a principal who directed and controlled the acts of murder and kidnapping [as the] Commander of the First Army."224 As commander-in-chief of the armed forces, Sánchez de Lozada also directly controlled the acts of the military. ${ }^{225}$ Therefore, the Bolivian Congress, like the Argentinean government, may successfully show probable cause for the charges against Sánchez de Lozada, holding him responsible for the military's actions as head of the armed forces. However, thc cases are distinguishable because SuarezMason first rose to power by military junta, whereas Sánchez de Lozada was voted into office in a legitimate election. ${ }^{226}$ In addition, while the Argentinean junta was responsible for widespread disappearances and individual acts of violence, the Sánchez de Lozada administration was not characterized by covert violence. ${ }^{227}$ Instead, Sánchez de Lozada allegedly directed the military to use deadly force to suppress national popular protests. ${ }^{228}$ Although it must be acknowledged that there are key differcnces in Sánchez de Lozada's case and that of Suarez-Mason, the latter's case still provides valuable guidance in assessing the political offense exception.

To successfully invoke the political offense exception, Sánchez de Lozada must satisfy both prongs of the incidence test: "(1) the occurrence of an uprising or other violent political disturbance at the time of the

220. Id.

221. Extradition Treaty, supra note 2, art. XII. The rule of speciality provides, "A person extradited under this Treaty shall not be detained, tried, convicted, [or] punished ... for an offense committed prior to surrender, cxcept with respect to: (a) an offense for which extradition was granted; (b) a different offense that is, nevertheless, constituted by the same facts on which extradition was granted; or (c) any other offense, provided the Requested State consents." $I d$.

222. Id.

223. In re Requestcd Extradition of Suarez-Mason, 694 F. Supp. 676, 685 (N.D. Cal. 1988).

224. Id.

225. Bolivia's Former President Charged With Genocide, supra note 6.

226. This makes a difference when utilizing the head of state immunity doctrine. In order to assert immunity, the governmental official must be recognized as a head of state. United States v. Noriega, 746 F. Supp. 1506, 1519-25 (S.D. Fla. 1990). This doctrine is not addressed in this Comment.

227. Bolivia's Former President Charged With Genocide, supra note 6.

228. Id. 
charged offense, and (2) a charged offense that is 'incidental to,' 'in the course of,' or 'in furtherance of' the uprising." ${ }^{229}$ First, Sánchez de Lozada must characterize the activity occurring in Bolivia at the time of his presidency as a revolutionary uprising. He would then claim that the protests were not peaceful and had degenerated into civilian violence. He would argue that the uprising was so intense that he was forced to direct the military to restore order in Bolivia, particularly in the areas surrounding the capital city. Considering the factual circumstances of the time, a court is likely to hold that the widespread protests constituted an uprising. Thus, Sánchez de Lozada would successfully satisfy the "uprising" prong of the incidence test.

With regard to the "incidental to" component of the incidence test, Sánchez de Lozada would argue that ordering military action was a direct response to the uprising. He would argue that his actions would not have been necessary had people merely protested peacefully. Again, based on the facts, a court likely would find a rational nexus between the acts and the uprising, and the "incidental to" prong would be satisfied. ${ }^{230}$ However, this rationalization leads directly to the paradoxical result that the Ninth Circuit warned about in Quinn and that was discussed in the previous section: if allowed to invoke the political offense exception as currently used by U.S. courts, Sánchez de Lozada would in fact receive special protection for violently suppressing an uprising. ${ }^{231}$

However, Bolivia could rebut the assertion that the "incidental to" prong is satisfied. In Suarez-Mason, the district court found that the alleged murders were not committed "incidental to" the uprising because there was no evidence that the victims were participants in any "violent or revolutionary activity."232 Bolivia could similarly argue that peaceful protesters were not engaged in any "violent or revolutionary activity." Bolivia also could show that the military injured and killed women and children who were not active participants in the protests, but who were innocent bystanders and victims of excessive military force. ${ }^{233}$

Existing interpretation of the "incidental to" prong might also support Bolivia's argument that Sánchez de Lozada cannot satisfy this component of the incidence test. The Ninth Circuit has recognized that the "incidental to" prong has been used interchangeably with "in the course of," "connected to," and "in furthcrance of.",234 Although the court supported a liberal construction of the nexus between the act and the uprising, Bolivia could argue that the above phrases could not be used interchangeably for

\footnotetext{
229. Quinn, 783 F.2d at 797.

230. See id. at 809 .

231. Id. at $800 \mathrm{n} .24$.

232. In re Requested Extradition of Suarez-Mason, 694 F. Supp. 676, 707 (N.D. Cal. 1988).

233. See generally Crisis and Justice, supra note 11.

234. Quinn, 783 F.2d at 809.
} 
Sánchez de Lozada's benefit. ${ }^{235}$ While his actions were "connected to" the uprising, they certainly were not "in furtherance" of the uprising, but rather operated to suppress the uprising.

Moreover, the Ninth Circuit stated that the "appropriate analogy to individuals acting in furtherance of an uprising is government officials acting in furtherance of a government policy, not in connection with an uprising." ${ }^{236}$ Scrutinizing Sánchez de Lozada's actions through this analogy, the question becomes whether he acted in furtherance of government policy. The inquiry would then be whether a relevant government policy existed, or whether Sánchez de Lozada simply used his executive power over the military to suppress an uprising. Possibly, Sánchez de Lozada did not act in the interest of the state, but in his own self-interest of maintaining his presidency, especially since he did not have the support of the Bolivian congress or his vice president as the violence escalated. ${ }^{237}$ Thus, if Sánchez de Lozada did not act in furtherance of a relevant government policy, the parallel to the Ninth Circuit's analogy does not hold. Bolivia also could argue that Sánchez de Lozada's reaction to the protests was disproportionate and excessively violent, and this lack of proportionality suggests that his actions were not in furtherance of a legitimate government policy.

Unfortunately, these arguments are unlikely to persuade courts in a country where the "incidence test" is firmly rooted. Courts have continued to apply the incidence test, unaltered and with little additional analysis, in the few cases that have involved government officials, even in those cases involving only financial crimes. If someone in Sánchez de Lozada's position is given almost automatic access to the political offense exception, any valid purpose for the exception will have been so perverted that the exception should not apply to any former government official.

However, if courts are willing to create a new test for the exception, molded to fit the circumstances of these actors, the exception could be logically maintained and used to protect former government officials from the unjust judicial processes that prompted the exception's original creation. Such a test would look beyond the political nature of the crime and involve an examination similar to the Swiss proportionality test discussed in Part III.A.1., infra. According to the Swiss test, if the crime is violent, "then the common element will outweigh the political motive unless such violence is the only means of achieving the end."238 Thus, a court would be mandated to examine the relationship between the acts committed and the government official's purpose in committing those acts. A court would also have to weigh whether any violence perpetrated was proportional or

235. See id.

236. Id. at 800 n.24.

237. Ledebur, supra note 25 , at 3.

238. GILBERT, supra note 117, at 235. 
necessary in a particular situation. In applying the Swiss test to Sánchez de Lozada's case, it is questionable whether the degree of force used by the military was proportional or necessary to quell the uprising. This illustrates that the Swiss test may be more useful than the incidence test in determining which former government officials should be permitted to assert the political offense exception.

\section{$\mathrm{V}$ \\ Conclusion: Lessons of Sánchez de Lozada's Case and the Future Application of the Political Offense Exception to Former Government OfFICIALS}

The Bolivian people face a difficult reality whether or not Sánchez de Lozada returns. Many people injured by the security forces still suffer physically, emotionally, and economically. Although Sánchez de Lozada's second term as president may not be comparable to a long-term repressive dictatorship, the Bolivian people still must come to terms with the past in order to mend their lives and work toward an improved relationship with their government. This relationship is decisively linked to how the future Bolivian administrations handle the process of Sánchez de Lozada's extradition.

Sánchez de Lozada's case is important for Bolivia and other governments facing transition, particularly Central and South American governments that have gone through similar changes in recent years. When popular support replaces one government with another, former government officials in exile are likely to employ any legal tool at their disposal to avoid extradition, even if their extradition is justifiable. The political offense exception exemplifies one such tool that affords protection to government officials when their actions are "incidental to an uprising" in their country. Under current case law, the political offense exception operates to unjustly protect those governmental leaders who use violence to suppress the rebellion of their citizens.

However, as described in this Comment, the political offense exception was not created to protect governments, but to protect those involved in political uprisings. ${ }^{239}$ The Ninth Circuit defines an uprising as "a revolt by indigenous people against their own government or an occupying power." 240 If the exception is to be used beyond its original purpose, courts must develop a new test in order to avoid the undesirable result of allowing actors like Sánchez de Lozada from using the exception as a defense to extradition. If government officials use violence to suppress a popular

239. At a minimum, courts already have expressed concem that the current incidence test used in applying the exception is inappropriate for former government officials. See, e.g., Barapind v. Enomoto, 360 F.3d 1061, 1075 (9th Cir. 2004), rev'd in part by 400 F.3d 744 (9th Cir. 2005) (en banc).

240. Quinn v. Robinson, 783 F.2d 776, 807 (9th Cir. 1986) 
uprising, the people should maintain their ability to prosecute those governmental actors for their crimes. 